\title{
The Main Dilemma and Countermeasures of Ideological and Political Education for Contemporary College Students
}

\author{
YE Ling Yan ${ }^{1, a}$ \\ ${ }^{1}$ Chongqing College of Electronic Engineering, Chongqing College Town, Shapingba District, Chongqing, China
}

A2603337901@qq.com

\begin{abstract}
Keywords: Contemporary College Students, Dilemma, Countermeasures, Ideological and Political
\end{abstract} Education

\begin{abstract}
As the world economic integration process, cultural diversity was evident, the information network and the diversification of forms of social organization and lifestyle tend to occur widespread social phenomenon of contemporary college students showed the distinctive characteristics of the times, Ideological political education is also facing unprecedented challenges. In this paper, starting from practical experience and summed up the characteristics of the times where the plight of contemporary college students caused by the contemporary ideological and political education, ideological and political education innovation practice of contemporary college students put forward some countermeasures.
\end{abstract}

\section{Introduction}

China's current development is in a global environment, the impact of globalization on China's comprehensive and profound. The process of globalization is a complex process of development of ever-changing, globalization should not be wrongly used as a simple unified process of change, but it should be seen as a complex change in tendency, the results are varied and often contradictory. The rapid development of China's productive forces, accelerating the pace of progress of human society, but due to subjective factors and the reality of the global strategy of the limitations that globalization inevitably brings a lot of difficulties for the Chinese economy and culture as relatively backward developing countries especially, the problem is more prominent.

In the process of globalization, cultural exchange between Western countries increasingly close, especially the few Western countries with their own strong scientific and technological strength, forced to spread their culture, resulting in the current domestic multicultural tit for tat, this conflict profound impact on the cultural affiliations of university students. If you cannot be guided many students will take the initiative to pursue the Western culture, which gradually lose the cultural identity of the nation, resulting in the decline of traditional national culture appeared on the dominance of Chinese socialist ideology and values shaken correctly It weakened the cultural cohesion countries, which for the development of the country and the nation is quite dangerous. Thus, with further accelerate the process of globalization, western culture and the increasingly fierce confrontation will go on long-term, this time working to strengthen the innovation of ideological and political education is particularly important.

\section{The Connotation of Ideological and Political Education}

Only the correct understanding of the true meaning of the ideological and political education in order to make the definition of ideological and political education gradually clear up. Based on the above understanding of the ideological and political education, the ideological and political education of college students is defined as: college students as a specific object of education, for college students political, legal education, but also for their ideals and beliefs, moral education; students with correct political views and legal concepts, but also to train students to establish a correct outlook on life and values education, to meet the specific needs of social practice and their own development. The definition of the ideological and political education requires attention to several aspects: First, pay attention to the object of education of the population is students, so that in 
the educational process Gao mention its relevance and effectiveness. Second, pay attention to the social ideological and political education, a feature that should meet the needs of the development of China's socialist characteristics. Finally, the ideological and political education is a process of interaction between educators and college students to enhance the ideological and political. Ideological and political education in educational practice throughout a person's life, whether educators or students, should be involved in this practice. In today's changing society, the rapid development background, educators and college students have to constantly improve their ideological and political quality, in order to meet their all-round development, to adapt to the changing social rhythm.

\section{The Dilemma of Ideological and Political Education}

Some College Students' Values Are Distorted. Today, Western countries with advanced information science and technology, their own ideology, values and lifestyles through its existing leading information technology delivery to China on China to infiltrate the realm of ideas, especially for College Students a major impact. They use "information hegemony" in many ways will be selling its ideology and values: First, world capitalism with color, life and values; second, on the physical and mental health toxic ethics and morals pornography and outlook on life; Third, creating all kinds of information on social disharmony, economic and political confusion. Because college students ideology is not enough strong, the difference between good and bad weak, poor plasticity, these factors have led college students when faced with bad information, more easily accept money worship, hedonism, extreme individualism as its values and goals in life formed a focus of interest is lighter than sacrifice, contempt for the moral value gains and losses, just remember to ignore serious personal and other collective phenomena, which students the correct outlook on life and values have serious obstacles.

Students' Socialist Faith Is Shaking. On the one hand, the West is certainly a powerful economic advantage of capitalism correctly, shake the appeal of socialism. In addition, the traveling of globalization, we have been carved Western countries bound by the rules. On the other hand, the US-led Western countries, with malice, their culture through cultural channels will penetrate into the socialist countries, to achieve the destruction of the dominant Marxist ideology. They call this silent evolution lies in Chinese adolescents, primarily on college students who thought just formed, so that they lifted ideologically armed and changed back into new equipment, in order to achieve the purpose of allowing them to manipulate. In the face of this reality, it is a minority of socialism will not firm, easily shaken students, no doubt its appeal and attractiveness will be greatly decreased, a few college students can easily follow socialist beliefs shaken.

Some Students Patriotism Is Weak. In which the background of globalization, the Western political system by the governance body diversity, awareness of the nation-state college students appear weakening. Objectively speaking, there is a diversification of the governance body of social management has a certain rationality, but also has great disadvantages. First, the Western countries to promote political pluralism excessive advantages, easy to make college students to the Chinese Communist Party leadership and centralized political system to generate suspicion and distrust from the ideology of the sovereign state appeared inevitable shake to the country the feasibility of the government's suspect, leading to university students appears divided on the issue of the nation a sense of belonging. Second, the much-vaunted Western individual-oriented values, greatly overshadowed Students sense of national responsibility, which is China-based social value is formed a strong impact. Some students in the future lead to the process of doing things only consider their own, all just for the sake of their own interests. Cultural exchange and learning, while Western societies to Chinese culture, transport, delivery is still a sense of his country's cultural coverage and aggression, trying to undermine the status of Students national culture, and thus dilute their national Culture. 
Establish the "Student-Centered" Educational Process. Humanism is the inherent requirement of socialism, the fundamental task of socialism is to emancipate and develop productive forces and the liberation and development of productive forces are the need of people to affect it, with the "human-oriented" relevant. Ideological and political education as working with people, the main purpose is to educate students, probation students, students, as the student body has always been the core of the ideological and political education. People-oriented as the core of the core concept of development, it has a very rich theoretical content: on the one hand, it is Marxist humanistic theory, is the inheritance of Marx's theory; the other hand, it is under new era Marxist Humanity enrich and develop the theory was given a new meaning salary.

Strengthening ideological and political theory course of construction, the external environment is the need to cope with the international struggle; to achieve socialist modernization needs; Students need to achieve comprehensive development. Ideological and Political Education adhere to the people-centered concept, it is necessary to highlight the dominant position of the educated, all modifications are to the development of students as the goal of education is "student-oriented", respect their personality, to meet their needs and achieve their value and promote their full development.

Establish the View of Process Interaction. The biggest weakness of Chinese traditional ideological and political education is to instill the main receiving education model and the biggest drawback is a serious lack of interaction between the educated ignored the initiative, as well as teachers and students. Such training mode, in the final analysis is simply a machine mode, simply is not conducive to the educated divergent thinking, is not conducive to the development of educated individuals. Modern ideological and political education tells us that the educational process is actually an active process of interaction between educators and the educated, mutual influence and promotes two-way interactive process of mutual restraint. Activities promoting the exchange of information between educators and the educated are more effective to the parties to speed up the processing of information and integration, and to respond quickly. Therefore, mutual interaction is an effective way to communicate. Modern educational research shows that there is no effective interaction between educators and educated, high efficient work of ideological and political education is difficult to achieve. Therefore, the university ideological and political education in the process and we should strengthen the concept of the need for interaction effects.

Interactive educational process, we must fully focus on the dominant position of the educated, educated to help understand ourselves, self-development and self-realization. Effective implementation of the ideological and political education must adhere to the following basic principles: the principle of heart to heart, emotional strength is great and it is both the understanding of faith into the catalyst, but also awareness into action boosters. To achieve effective interaction ideological and political education, we should bear in mind the importance of the principles to ingratiate them. Only education parties in achieving honest, sincere exchange, in order to mobilize the enthusiasm of students, student teachers teaching content cannot doubt that, even if the teacher is respected, learning efficiency has also been improved, so as to achieve the effectiveness of ideological and political education. Thus, the first principle is to ingratiate them to achieve ideological and political education to interact. The main principles of ideological and political education in colleges and universities, both sides have a strong educational independence, self-sex. If it is not equal dialogue between them, cannot communicate heart to heart, is not convincing accept each other, cannot be achieved ideological and political education effectiveness, scientific, artistic.

Adhere to Create Service Concept of Devotional Society. Era of knowledge economy, higher education increasingly become the focus of the era of modern society, higher education for the prosperity and social development of the country has played a huge role in promoting. Building society, the key is talent, based on a direct relationship between the levels of education, education to the future development of the country. School education have educational, scientific and cultural level of educational scientific and cultural education and ideas directly determine the ability of ideological education level building society directly determine the direction and the construction of 
attitude, although the distinction between the two, but its content interspersed with each other, you have me, I have you, complement each other and common development. Over the years, our party has been the ideological and political education to the success of the revolution as a weapon to protect. While it's far from the revolutionary struggle, but ideological and political education is still important, the party is still magic to guide the construction of socialism.

Ideological and political education in the social construction of demonstration content should be the socialist core value system. Socialist core value system is the social system to be functioning, social order to maintain the basic spiritual support, which includes guiding ideology of Marxism, the common ideal of socialism with Chinese characteristics, with patriotism as the core of the national warning and socialist concept of honor. Only give full play to the exemplary role of ideological and political education in construction, and in the whole society has a broad appeal of socialist core value system, to expand the recognition of differences, increase consensus on inclusion, the struggle for national unity and lay ideological foundation.

\section{Conclusions}

Ideological and political education is the fine tradition of the Chinese Communist Party is an important party in the capital during the revolution indispensable, living in an extremely important position in the party's cause. Communist Party of China has accumulated rich experience in ideological and political education in the long process of socialist revolution and construction and had made significant achievements in theory and practice. With the trend of globalization and the establishment of China's socialist market economic system development, people's thinking, behavior has undergone tremendous changes, which for ideological and political education of a higher requirement. Ideological and political education ideological and political education as an important branch, also suffered a very serious dilemma. Therefore, the study ideological and political education has great significance in the current environment.

\section{References}

[1] Haidong Ni: Journal of Shenyang Administrative Cadres, Vol. 6 (2004) No 53, p.25-26

[2] Hongli Zhang: Ideological Education Research, Vol. 12 (2005) No 27, p.74-76

[3] Qin Guo: Research on Ideological and Political Education, Vol. 1 (2006) No 33, p.11-14

[4] Jieming Liu: Guangxi Normal University, Vol. 3 (2007) No33, p.121-124

[5] Xuesen Cui: Liaoning Normal University, Vol. 1 (2008) No 15, p.58-62 